www.jmscr.igmpublication.org

Impact Factor 5.84

Index Copernicus Value: 71.58

ISSN (e)-2347-176x ISSN (p) 2455-0450

crossref DOI: _https://dx.doi.org/10.18535/jmscr/v5i12.86

Journal Of Medical Science And Clinical Research

\title{
Prevalence of Vitamin-D Deficiency in HIV Positive Patients and its Correlation with Occurrence of Opportunistic Infections and CD4 Counts
}

\author{
Authors \\ Dr Sivaprakash Varadan ${ }^{1}$, Dr Sudagarsingh. $\mathbf{R B}^{2}$, Chandu $\mathbf{P}^{3}$, Dr Vasanthan ${ }^{4}$ \\ Dr Damodharan $\mathbf{J}^{\mathbf{5}}$ \\ ${ }^{1}$ Assistant Professor, ${ }^{2,5}$ Professor, ${ }^{3}$ Postgraduate, ${ }^{4}$ Associate Professor \\ Corresponding Author \\ Dr Sivaprakash Varadan \\ Assistant Professor
}

\begin{abstract}
The vitamin $D$ endocrine system plays an essential role in calcium homeostasis and bone metabolism required for optimal absorption of dietary calcium and phosphate. Apart from role in calcium homeostasis other biological actions include induction of cell differentiation, inhibition of cell growth, immunomodulation and control of other hormonal systems. Several studies have demonstrated low serum vitamin 25(OH)D levels in populations across India. Very high percentage of HIV -infected people live in areas of the world where nutritional deficiencies are also highly prevalent, and the interactions between HIV and nutritional status have been documented. In last few years there have been reports suggesting an increased prevalence of osteopenia and osteoporosis in HIV positive patients ${ }^{7,8,9}$. Middle-aged persons with human immunodeficiency virus (HIV) infection are at risk for numerous co-morbidities typically seen including metabolic syndrome, osteoporosis and fractures, insulin resistance, diabetes, cardiovascular disease, cognitive impairment and opportunistic infection. Many of which have also been associated with vitamin $D$ deficiency.

HIV infection and exposure to certain antiretroviral might contribute to altered levels of 25(OH) vitamin D.Vitamin D insufficiency or deficiency may increase the incidence of opportunistic infection in HIV patients. Vitamin D level in HIV patients and its co-relation with opportunistic infection and immunological status are not yet well defined. Therefore present study is designed to find the correlation between HIV status and vitamin D levels.
\end{abstract}

\section{Aim and Objective}

To Measure the Vitamin-D Levels in HIV Positive Patients (PLHA) and Controls, then to Correlate with Opportunistic Infections, CD4 Count and Duration of Art.

\section{Background}

The prevalence of low $25(\mathrm{OH}) \mathrm{D}$ levels $<20$ $\mathrm{ng} / \mathrm{mL}$ [50 nmol/L]) is approximately36\% in otherwise healthy young adults aged 18 to 29 years. Prevalence of inadequate $25(\mathrm{OH}) \mathrm{D}$ levels is high in post menopausal women and especially 
those with osteoporosis and a history of fracture. More than $90 \%$ of $\mathrm{HI} \mathrm{V-infected} \mathrm{people} \mathrm{live} \mathrm{in}$ areas of the world where nutritional deficiencies are also highly prevalent, and the interactions between HIV and nutritional status have been widely documented. Deficiencies of several micronutrients have been associated with increased rates of progression to AIDS and HIV related mortality. ${ }^{5}$

\section{Materials and Methods}

This study was carried out in Department of General Medicine at Sri Ramachandra Medical College and Research Institute, a tertiary care referral hospital in Chennai India. The study was approved by Institutional Ethics Committee and a written informed consent was obtained from all patients prior to inclusion. The study subjects included 50 HIV positive patients and HIV non reactive individuals who are (aged more than 18 years) admitted to the hospital or following ART clinic in Sri Ramachandra Medical College and Hospital.

\section{Inclusion Criteria}

- $\quad$ ART naive HIV positive patients attending ART clinic at Sri Ramachandra Medical College

- Both, Male \& Female patients will be included

- Age> 18 yrs

- Patients willing to give informed consent

\section{Exclusion Criteria}

- Patients on Vitamin D supplementation in last one month.

- Pregnant women

\section{Methodology}

All patients were subjected to detailed history and clinical examination using a pre-designed Performa. Data concerning the patients' age, gender, date of diagnosis of HIV status, drug intake, occupation. Patients categorized in different clinical stages as per NACO guidelines. Blood samples were collected on the day of interview. Fasting venous samples of all study subjects were drawn in calcium free test tubes. Serum was separated in a refrigerated centrifuge at $800 \mathrm{x} \mathrm{g}$ for 15 minutes at $4{ }^{\circ} \mathrm{C}$. CD4 count done by FACS count method. The complete hemogram, serum urea, creatinine, bilirubin, aspartate aminotransferase, and alanine aminotransferase levels, coinfections like $\mathrm{HbsAg}$ and $\mathrm{HCV}$ was included were checked to examine liver and renal function.

The samples were stored at $-70^{\circ} \mathrm{C}$ until analyzed, and were protected from light during processing. All serum concentrations of $25(\mathrm{OH})$ D were measured by chemiluminescent micro particle immunoassay in the Nuclear Medicine laboratory of Sri Ramachandra Medical College and Research Institute. The sensitivity of the method is $<1.5 \mathrm{ng} / \mathrm{ml}$. Vitamin D deficiency was defined as deficiency $<20 \mathrm{ng} / \mathrm{ml}$, insufficiency is $21-30$ $\mathrm{ng} / \mathrm{ml}$, sufficiency is $>30 \mathrm{ng} / \mathrm{ml}$.

\section{Statistical Analysis}

Analysis was performed using SPSS. Quantitative data were expressed as means \pm SD. Qualitative data expressed as percentage. Difference between the two means was performed using Student " $t$ " test (if data was normally distributed), or MannWhitney $U$ test (if data was not normally distributed). Correlations were examined using Spearman's rank correlation test. Chi- square test was used to assess differences in the proportion between qualitative data.

\section{Results}

A total of $50 \mathrm{HIV}$ patients and 50 non reactive individuals were included in the study for comparing vitamin D levels and its correlation with opportunistic infections and CD4 count

Table 1 T-Test

\begin{tabular}{|c|c|c|c|c|c|}
\hline GROUP & N (100) & Mean (Age) & Std. Deviation & Std. Error Mean & P Value \\
\hline HIV & 50 & 44.08 & 11.998 & 1.697 & 0.000 \\
\hline CONTROL & 50 & 30.66 & 6.249 & 0.884 & \\
\hline
\end{tabular}




\begin{tabular}{|l|c|c|c|}
\hline \multirow{2}{*}{ Age } & \multicolumn{2}{|c|}{ GROUP } & \\
\cline { 2 - 4 } & HIV & CONTROL & TOTAL \\
\hline 20-30 Years & $4(8.0 \%)$ & $22(44.0 \%)$ & $26(26.0 \%)$ \\
\hline 31-40 Years & $19(38.0 \%)$ & $27(54.0 \%)$ & $46(46.0 \%)$ \\
\hline 41-50 Years & $14(28.0 \%)$ & $1(2.0 \%)$ & $15(15.0 \%)$ \\
\hline 51-60 Years & $9(18.0 \%)$ & $0(0 \%)$ & $9(9.0 \%)$ \\
\hline$>60$ Years & $4(8.0 \%)$ & $0(0 \%)$ & $4(4.0 \%)$ \\
\hline Total & $50(100.0 \%)$ & $50(100.0 \%)$ & $100(100.0 \%)$ \\
\hline
\end{tabular}

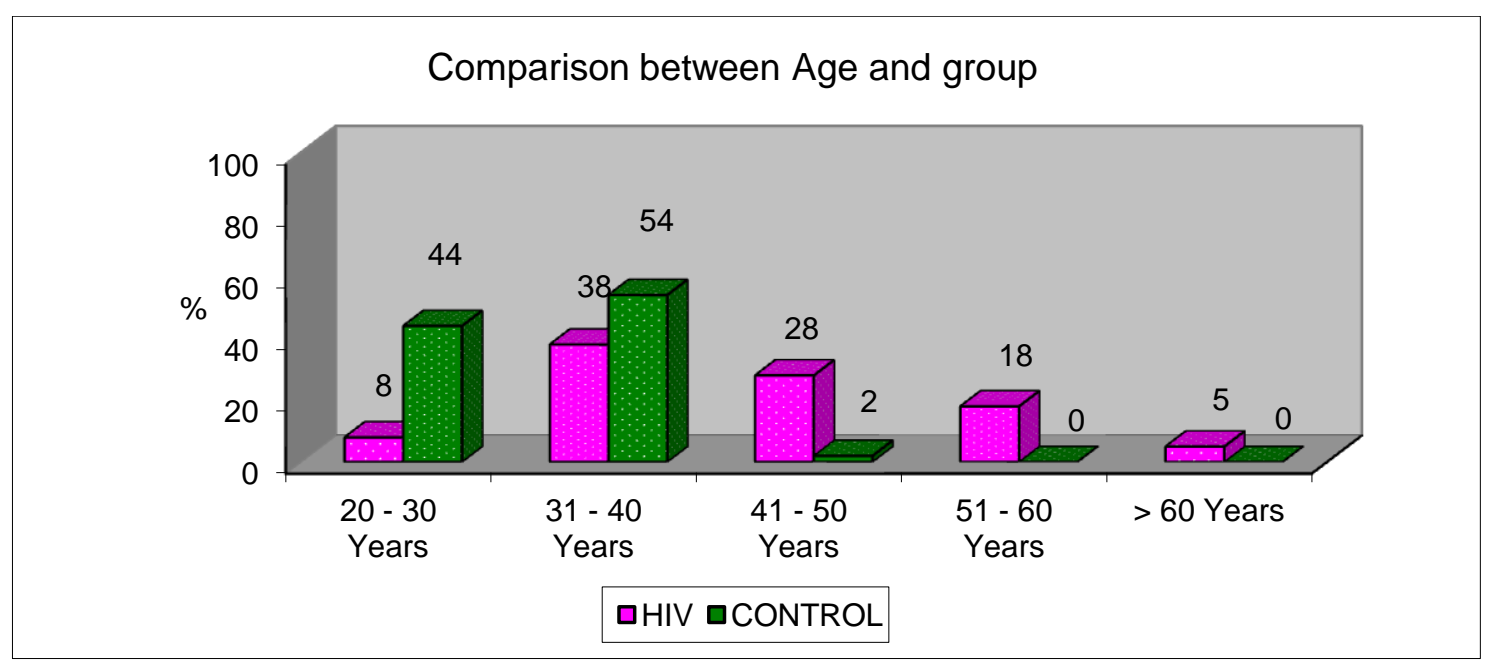

In our study age groups were compared in which 4 (8\%) patients was in HIV and 22 (44\%) was in control. In age group 31-40 years 19 (38\%) was HIV patients 27 (54\%) was control. In 41-50 years
$14(28 \%)$ was HIV, 1 (2\%) was in control. $51-60$ years $9(18 \%)$ patients was HIV and 0 was in control. In $>60$ years 4 patients $(8 \%)$ was HIV, 0 was in control.

\section{Table 2 Crosstabs}

\begin{tabular}{|l|c|c|c|c|}
\hline \multirow{2}{*}{ SEX } & \multicolumn{2}{|c|}{ GROUP } & \multirow{2}{*}{ TOTAL } & \multirow{2}{*}{ P Value } \\
\cline { 2 - 3 } & HIV & CONTROL & & \\
\hline Male & $36(72 \%)$ & $30(60 \%)$ & $66(66 \%)$ & \multirow{2}{*}{0.205} \\
\hline Female & $14(28 \%)$ & $20(40 \%)$ & $34(34 \%)$ & \\
\hline Total & $50(100 \%)$ & $50(100 \%)$ & $100(100 \%)$ & \\
\hline
\end{tabular}

Chi-Square Tests

\begin{tabular}{|c|c|c|c|c|c|}
\hline & Value & $\mathrm{df}$ & $\begin{array}{c}\text { Asy mp. Sig. } \\
\text { (2-sided) }\end{array}$ & $\begin{array}{l}\text { Exact Sig. } \\
\text { (2-sided) }\end{array}$ & $\begin{array}{l}\text { Exact Sig. } \\
\text { (1-sided) }\end{array}$ \\
\hline Pearson Chi-Square & $1.604^{b}$ & $\overline{1}$ & .205 & & \\
\hline Continuity Correctior & 1.114 & 1 & .291 & & \\
\hline Likelihood Ratio & 1.611 & 1 & .204 & & \\
\hline Fisher's Exact Test & & & & .291 & .146 \\
\hline $\begin{array}{l}\text { Linear-by-Linear } \\
\text { Association }\end{array}$ & 1.588 & 1 & .208 & & \\
\hline N of Valid Cases & 100 & & & & \\
\hline
\end{tabular}

a. Computed only for a $2 \times 2$ table

b. 0 cells $(.0 \%)$ have expected count less than 5 . The minimum expected count is 17 . 00 . 

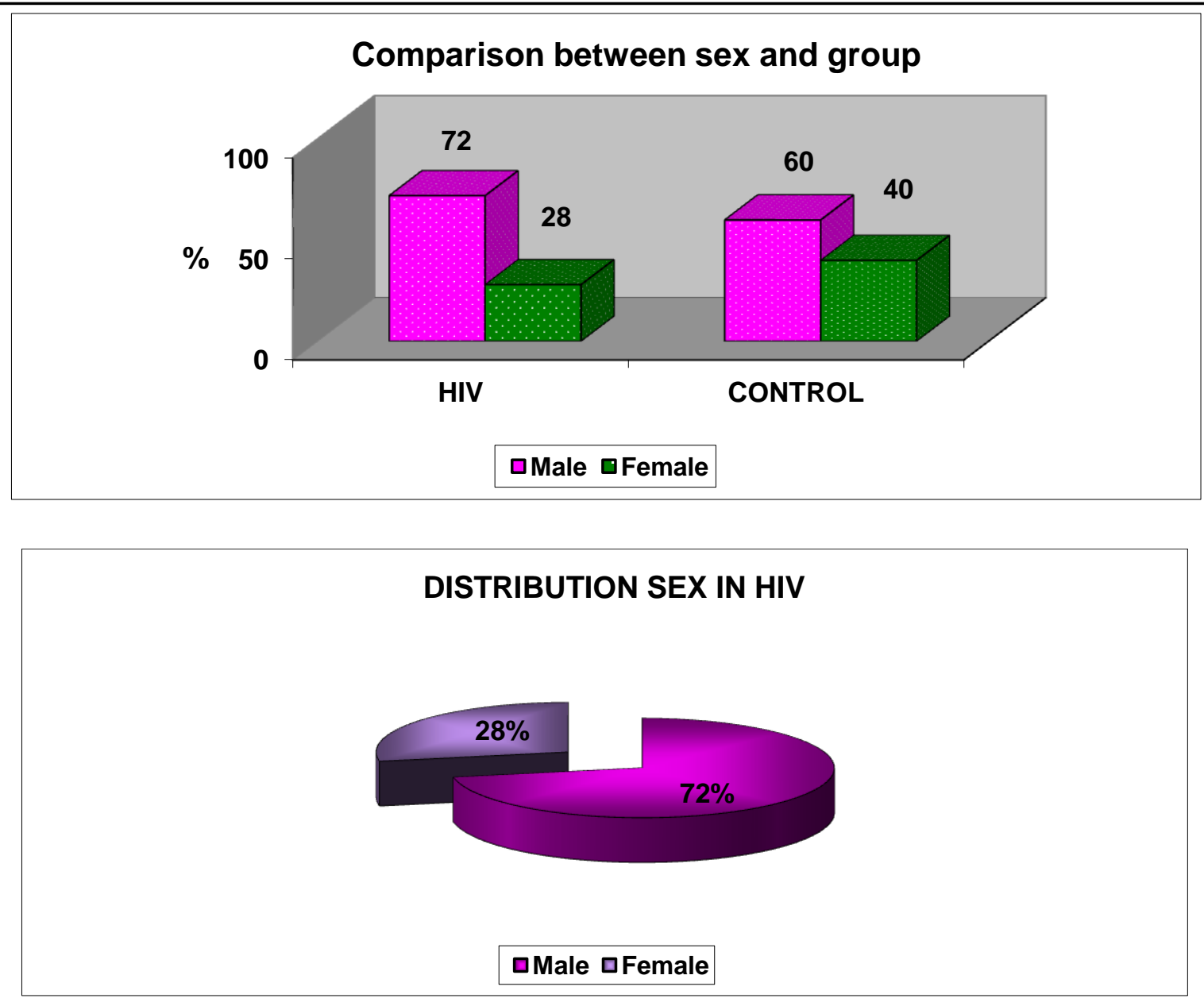

\section{DISTRIBUTION SEX IN CONTROL}

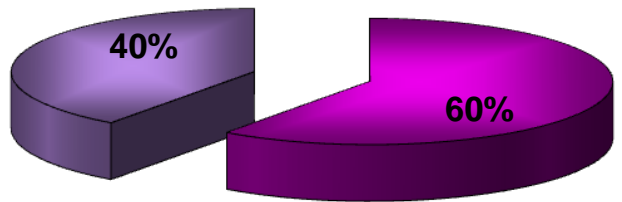

In our study HIV group contains $36(72 \%)$ males, $14(28 \%)$ females whereas in control group 30 $(60 \%)$ was male and $20(40 \%)$ was females.
We compared $25(\mathrm{OH}) 2$ Vitamin D level in HIV patient of which 37 (74\%) patients were vit D deficient $(<20 \mathrm{ng} / \mathrm{ml})$ and in the control group 27 patients (54\%) are vit $\mathrm{D}$ deficient.

Table 3 T-Test

\begin{tabular}{|c|c|c|c|c|c|}
\hline GROUP & N (100) & $\begin{array}{c}\text { Mean } \\
(25 \mathrm{OH} \mathrm{ng} / \mathrm{ml})\end{array}$ & Std. Deviation & $\begin{array}{c}\text { Std. Error } \\
\text { Mean }\end{array}$ & P Value \\
\hline HIV & 50 & 16.126 & 7.2032 & 1.0187 & 0.024 \\
\hline CONTROL & 50 & 20.494 & 9.7632 & 1.3807 & \\
\hline
\end{tabular}




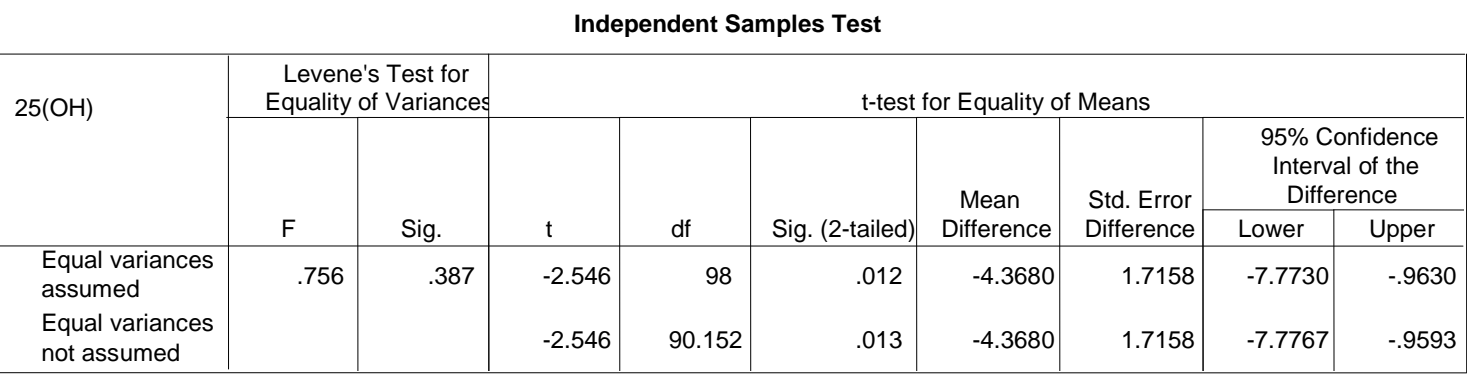

\section{Crosstabs}

\begin{tabular}{|c|c|c|c|c|}
\hline \multirow{2}{*}{$\begin{array}{c}25(\mathrm{OH}) \text { Vit D } \\
(\mathrm{ng} / \mathrm{ml})\end{array}$} & \multicolumn{2}{|c|}{ GROUP } & \multirow{2}{*}{ TOTAL } & \multirow{2}{*}{ P Value } \\
\cline { 2 - 3 } & HIV & CONTROL & & \\
\hline$<20$ & $37(74 \%)$ & $27(54 \%)$ & $64(64 \%)$ & \multirow{2}{*}{0.05} \\
\hline $21-30$ & $12(24 \%)$ & $17(34 \%)$ & $29(29 \%)$ & \\
\hline$>30$ & $1(2 \%)$ & $6(12 \%)$ & $7(7 \%)$ & \\
\hline Total & $50(100 \%)$ & $50(100 \%)$ & $100(100 \%)$ & \\
\hline
\end{tabular}

Chi-Square Tests

\begin{tabular}{|l|c|r|r|}
\hline & Value & df & \multicolumn{1}{|c|}{$\begin{array}{c}\text { Asymp. Sig. } \\
\text { (2-sided) }\end{array}$} \\
\hline Pearson Chi-Square & $5.996^{\mathrm{a}}$ & 2 & .050 \\
Likelihood Ratio & 6.398 & 2 & .041 \\
Linear-by-Linear & 5.784 & & 1 \\
Association & 100 & & .016 \\
Nof Valid Cases & & \\
\hline
\end{tabular}

a. 2 cells $(33.3 \%)$ have expected count less than 5 . The minimum expected count is 3.50 .

\section{Comparison between 25(OH) Vit $D$ and group}

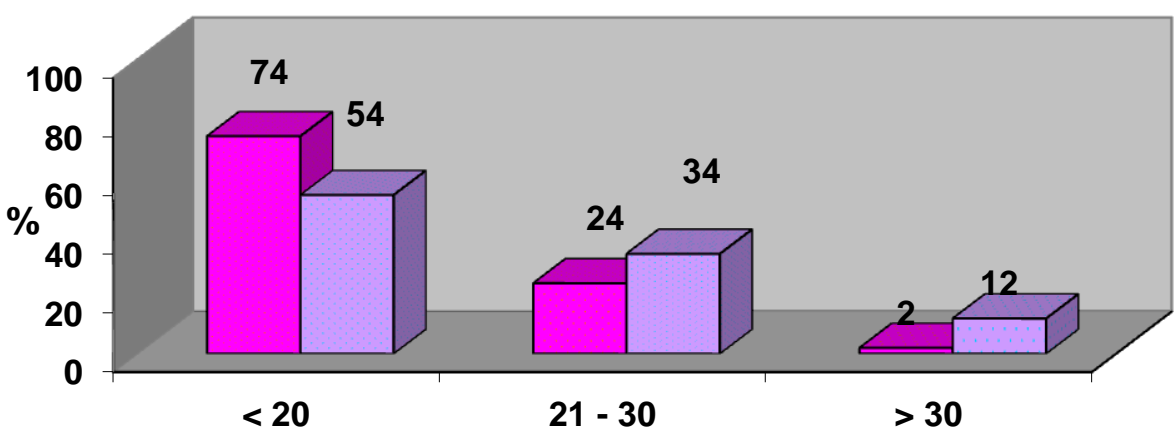

口HIV 口CONTROL

In our study we compared vitamin D levels in HIV group and control group of, HIV patients had vitamin D deficiency $(<20 \mathrm{ng} / \mathrm{ml})$, compared to

\section{Crosstabs}

Table 4 Oppurtunistic infections * 25(OH) Vit D

\begin{tabular}{|c|c|c|c|c|}
\hline \multirow{2}{*}{$\begin{array}{c}25(\mathrm{OH}) \text { Vit D } \\
(\mathrm{ng} / \mathrm{ml})\end{array}$} & \multicolumn{2}{|c|}{ Opportunistic Infection } & \multirow{2}{*}{ Total } & P Value \\
\cline { 2 - 3 } & Yes & No & & \\
\hline$<20$ & $30(60 \%)$ & $7(14 \%)$ & $37(74 \%)$ & 0.006 \\
\hline $21-30$ & $4(8 \%)$ & $8(16 \%)$ & $12(24 \%)$ & \\
\hline$>30$ & $1(2 \%)$ & $0(0 \%)$ & $1(2 \%)$ & \\
\hline
\end{tabular}


Chi-Square Tests

\begin{tabular}{|c|c|c|c|}
\hline & Value & df & $\begin{array}{l}\text { Asy mp. Sig. } \\
\text { (2-sided) }\end{array}$ \\
\hline Pearson Chi-Square & $10.275^{a}$ & 2 & .006 \\
\hline Likelihood Ratio & 9.917 & 2 & .007 \\
\hline $\begin{array}{l}\text { Linear-by-Linear } \\
\text { Association }\end{array}$ & 5.578 & 1 & .018 \\
\hline N of Valid Cases & 50 & & \\
\hline
\end{tabular}

a. 3 cells $(50.0 \%)$ have expected count less than 5 . The minimum expected count is .30 .

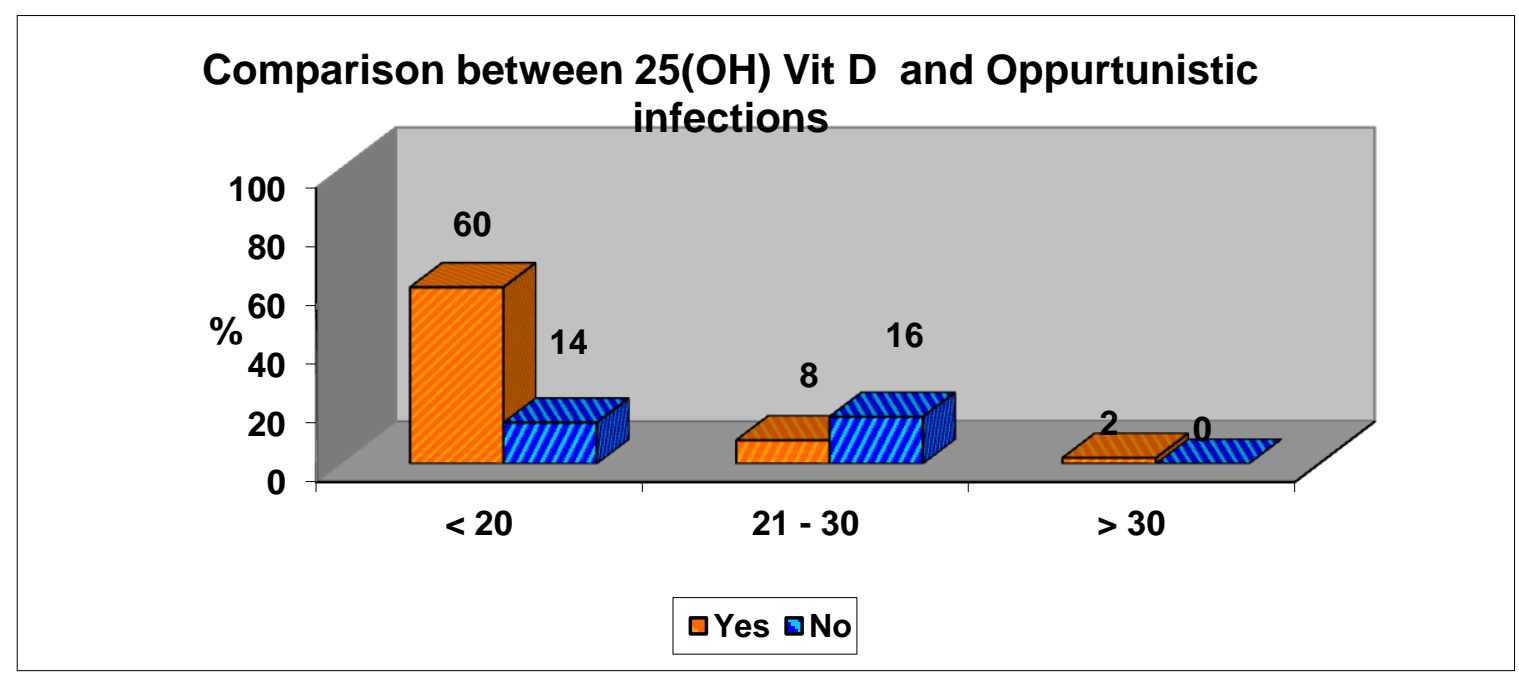

In our study oral candidiasis most commonly found opportunistic infection when we compared $25(\mathrm{OH}) 2$ Vitamin D levels with opportunistic infections in HIV patients, they had vitamin D deficiency $(<20 \mathrm{ng} / \mathrm{ml})$, which was statistically significant of $\mathrm{P}$ value being 0.108 .

Table 5 ART * 25(OH) Vit D

\begin{tabular}{|c|c|c|c|c|}
\hline \multirow{2}{*}{$\begin{array}{c}25(\mathrm{OH}) \text { Vit D } \\
(\mathrm{ng} / \mathrm{ml})\end{array}$} & \multicolumn{2}{|c|}{ ART } & \multirow{2}{*}{ Total } & \\
\cline { 2 - 3 } & Yes & No & & \multirow{2}{*}{0.239} \\
\hline$<20$ & $30(60 \%)$ & $7(14 \%)$ & $37(74 \%)$ & \\
\hline $21-30$ & $12(24 \%)$ & $0(0 \%)$ & $12(24 \%)$ & \\
\hline$>30$ & $1(2 \%)$ & $0(0 \%)$ & $1(2 \%)$ & \\
\hline
\end{tabular}

Chi-Square Tests

\begin{tabular}{|c|c|c|c|}
\hline & Value & $\mathrm{df}$ & $\begin{array}{c}\text { Asy mp. Sig. } \\
\text { (2-sided) }\end{array}$ \\
\hline Pearson Chi-Square & $2.860^{\mathrm{a}}$ & 2 & .239 \\
\hline Likelihood Ratio & 4.603 & 2 & .100 \\
\hline $\begin{array}{l}\text { Linear-by-Linear } \\
\text { Association }\end{array}$ & 2.588 & 1 & .108 \\
\hline N of Valid Cases & 50 & & \\
\hline
\end{tabular}

a. 3 cells $(50.0 \%)$ have expected count less than 5 . The minimum expected count is .14 . 


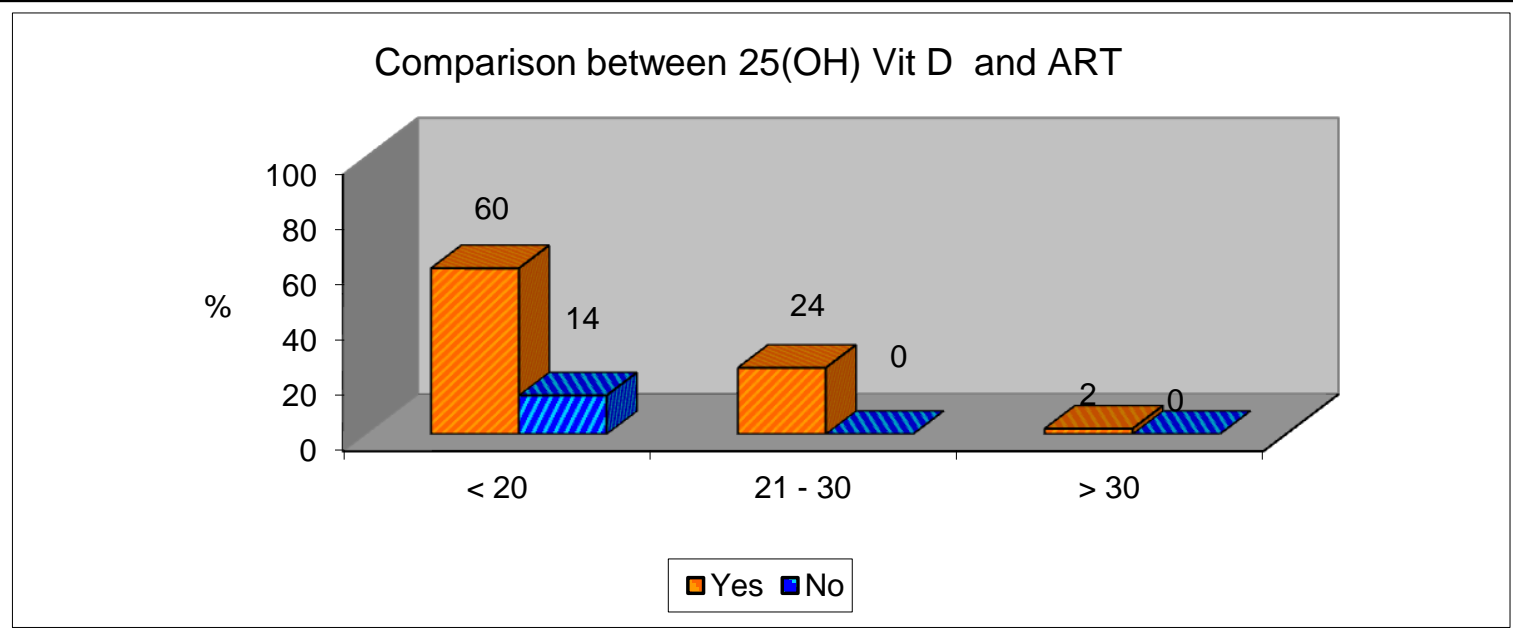

When we compared $25(\mathrm{OH}) 2$ vitamin D levels in deficient $(<20 \mathrm{ng} / \mathrm{ml})$, and statistically not patients on ART $25(\mathrm{OH}) 2$ vitamin D level was significant $\mathrm{P}$ value being 0.239 .

Table 6 HBsAg * 25(OH) Vit D

\begin{tabular}{|c|c|c|c|c|}
\hline \multirow{2}{2}{$\begin{array}{c}25(\mathrm{OH}) \text { Vit D } \\
(\mathrm{ng} / \mathrm{ml})\end{array}$} & \multicolumn{2}{|c|}{ HBsAg } & \multirow{2}{*}{ Total } & \\
\cline { 2 - 3 } & Yes & No & & \multirow{2}{*}{0.622} \\
\hline$<20$ & $7(14 \%)$ & $30(60 \%)$ & $37(74 \%)$ & \\
\hline $21-30$ & $1(2 \%)$ & $11(22 \%)$ & $12(24 \%)$ & \\
\hline$>30$ & $0(0 \%)$ & $1(2 \%)$ & $1(2 \%)$ & \\
\hline
\end{tabular}

Chi-Square Tests

\begin{tabular}{|c|c|c|c|}
\hline & Value & $\mathrm{df}$ & $\begin{array}{l}\text { Asy mp. Sig. } \\
\text { (2-sided) }\end{array}$ \\
\hline Pearson Chi-Square & $.950^{a}$ & 2 & .622 \\
\hline Likelihood Ratio & 1.190 & 2 & .552 \\
\hline $\begin{array}{l}\text { Linear-by-Linear } \\
\text { Association }\end{array}$ & .928 & 1 & .335 \\
\hline N of Valid Cases & 50 & & \\
\hline
\end{tabular}

a. 3 cells $(50.0 \%)$ have expected count less than 5 . The minimum expected count is .16 .

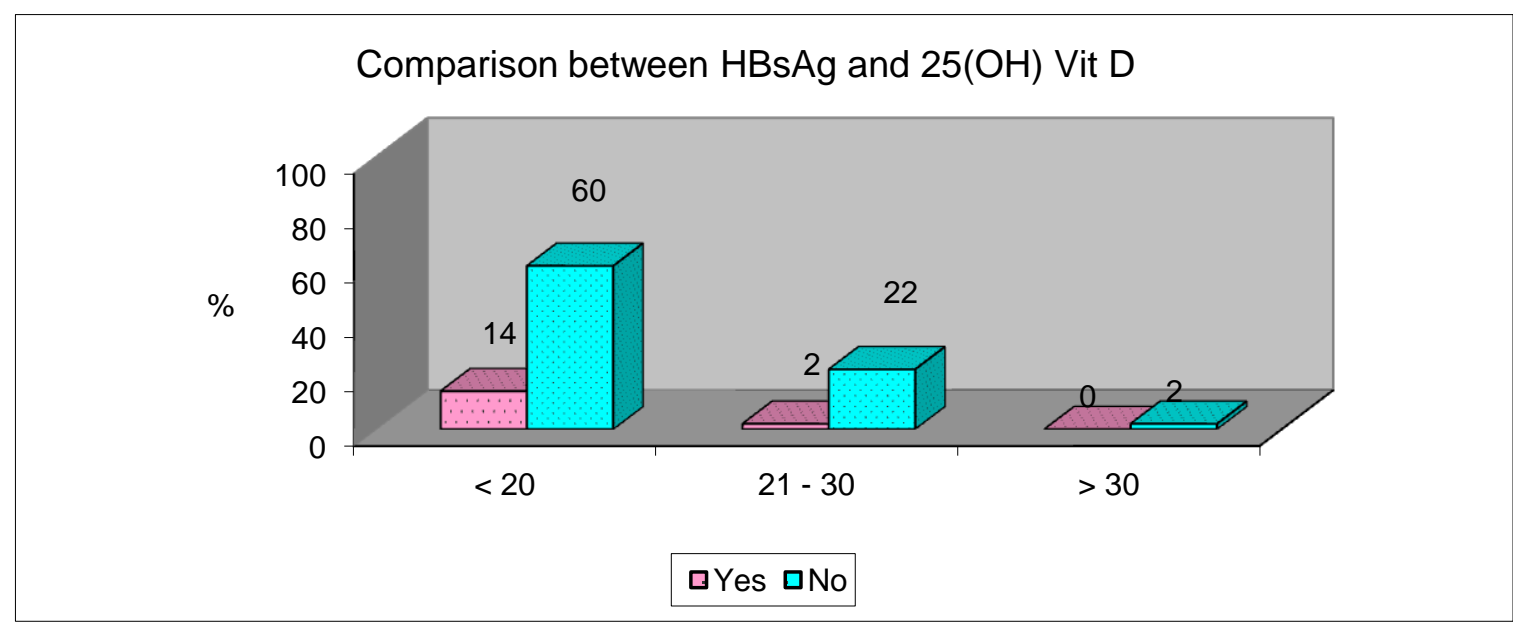

When we compared $25(\mathrm{OH}) 2$ vitamin D levels in HBsAg positive patients vitamin D level was statistically not significant of $\mathrm{P}$ value being 0.622 . 
Table $7 \mathrm{HCV} * 25(\mathrm{OH})$ Vit D

\begin{tabular}{|c|c|c|c|c|}
\hline \multirow{2}{*}{$\begin{array}{c}25(\mathrm{OH}) \text { Vit } \mathrm{D} \\
(\mathrm{ng} / \mathrm{ml})\end{array}$} & \multicolumn{2}{|c|}{ HCV } & \multirow{2}{*}{ Total } & P Value \\
\cline { 2 - 3 } & Yes & No & & \\
\hline 220 & $1(2 \%)$ & $36(72 \%)$ & $37(74 \%)$ & \multirow{2}{*}{0.836} \\
\hline $21-30$ & $0(0 \%)$ & $12(24 \%)$ & $12(24 \%)$ & \\
\hline$>30$ & $0(0 \%)$ & $1(2 \%)$ & $1(2 \%)$ & \\
\hline
\end{tabular}

Chi-Square Tests

\begin{tabular}{|l|r|r|r|}
\hline & Value & df & $\begin{array}{c}\text { Asy mp. Sig. } \\
\text { (2-sided) }\end{array}$ \\
\hline Pearson Chi-Square & $.359^{\mathrm{a}}$ & 2 & .836 \\
Likelihood Ratio & .609 & 2 & .737 \\
Linear-by-Linear & .325 & 1 & .569 \\
Association & 50 & & \\
N of Valid Cases & & \\
\hline
\end{tabular}

a. 4 cells $(66.7 \%)$ have expected count less than 5 . The minimum expected count is .02 .

\section{Comparison between HCV and 25(OH) Vit D}

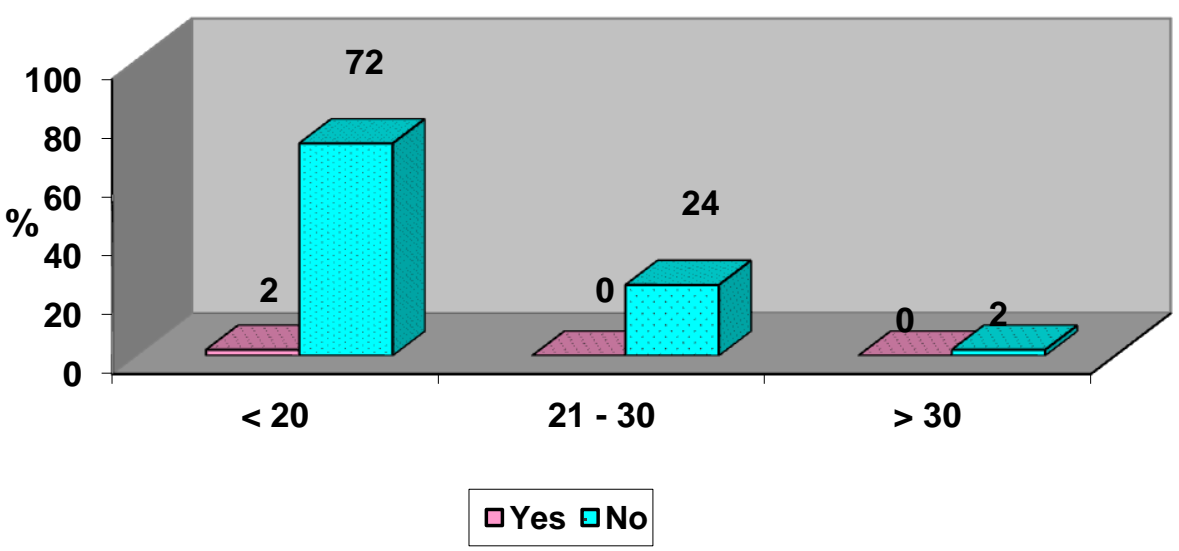

When we compared $25(\mathrm{OH}) 2$ vitamin D levels in HCV patients vitamin D level was statistically not significant $\mathrm{P}$ value being 0.836 .

\section{Table 8}

\begin{tabular}{|c|c|c|c|c|}
\hline \multirow{2}{*}{ CD4 } & \multicolumn{3}{|c|}{$25(\mathrm{OH}) \mathrm{Vit} \mathrm{D}(\mathrm{ng} / \mathrm{ml})$} & \multirow{2}{*}{ P Value } \\
\cline { 2 - 4 } & $<20$ & $21-30$ & $>30$ & \\
\hline$<200$ & 60 & 8 & 0 & \multirow{2}{*}{0.015} \\
\hline $200-350$ & 6 & 6 & 2 & \\
\hline$>350$ & 8 & 10 & 0 & \\
\hline
\end{tabular}

ANOV A

\begin{tabular}{|c|c|c|c|c|c|}
\hline & $\begin{array}{l}\text { Sum of } \\
\text { Squares }\end{array}$ & $\mathrm{df}$ & Mean Square & $\mathrm{F}$ & Sig. \\
\hline Betw een Groups & 627284.5 & 2 & 313642.230 & 4.587 & .015 \\
\hline Within Groups & 3213961 & 47 & 68382.139 & & \\
\hline Total & 3841245 & 49 & & & \\
\hline
\end{tabular}




\section{JMSCR Vol||05||Issue||12||Page 31808-31819||December}

\section{COMPARISON BETWEEN CD4 COUNT AND 25(OH) VIT D}

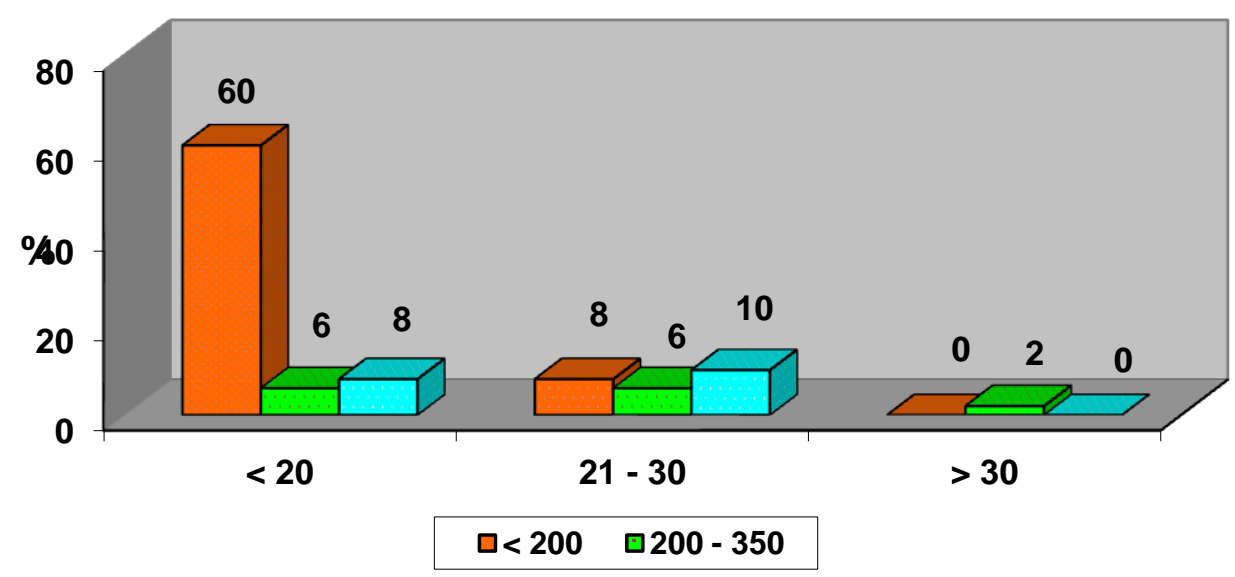

\section{CD4 COUNT}

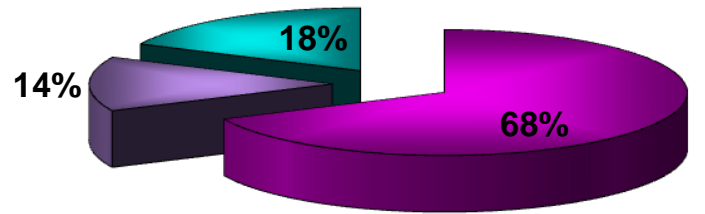

$\square<200 \square 200-350 \square>350$

Patients with CD4 count $<100$ had vitamin D deficiency $(<20 \mathrm{ng} / \mathrm{ml}), \mathrm{P}$ value being 0.015 , statistically significant.

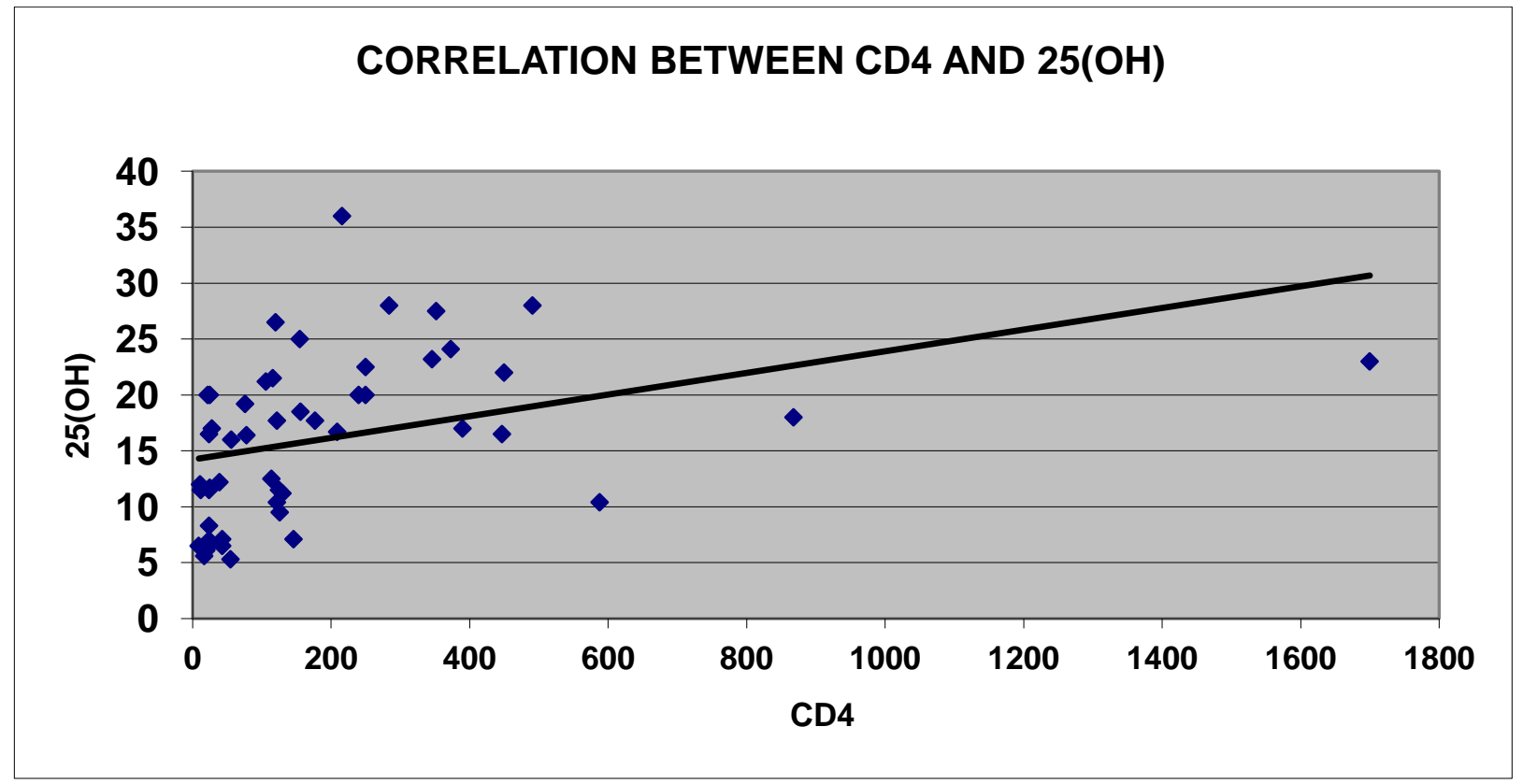

The above scattered diagram shows $25(\mathrm{OH})$

vitamin $\mathrm{D}$ is low in patient with low CD4 count. 


\section{Discussion}

In our study we have taken 50 HIV positive patients and $50 \mathrm{HIV}$ non reactive individuals. We have measured the $25(\mathrm{OH}) 2$ vitamin D levels in HIV positive patients (PLHA) and controls, and then correlated with opportunistic infections, CD4 count and duration of ART.

\section{Prevalence and Age}

The key findings in our study suggest that there is a high prevalence of vitamin D deficiency in HIV positive patients (74\%), when compared to HIV non reactive individuals was $54 \%$, which is statistically siginificant (Table 3). There is trend suggesting the positive association between the vitamin D deficiency and advanced clinical stage of HIV disease, but not statistically significant.

In a similar study conducted by Christine N. Dao et $\mathrm{al}^{13}$ showed high prevalence of vitamin $\mathrm{D}$ deficiency affecting $>70 \%$ of HIV infected persons, however no controls were used in the study.

\section{Age}

In our study maximum number of HIV positive individuals come under the age group 31 to 40 years about 19 (38\%) individuals , and in HIV negative individuals is $27(54 \%)$ comes under the age group of 31 to 40 years.

In our study the mean age group in HIV positive patients is 44.08 and HIV negative individuals is 30.66 (Table 1).There is a statistical significance of mean age group between HIV positive individuals and HIV negative controls using independent sample test.

Study conducted by Charles B Stephensen et al showed the prevalence of vitamin D insufficiency in subjects aged 12 to 29 years which was $32 \%$. In women aged 15 to 49 years from the same survey, the prevalence of insufficiency (21 -30 $\mathrm{ng} / \mathrm{ml}$ ) was $42 \%$.

\section{Sex Distribution}

In our study, HIV positive patients contains 36 (72\%) male, 14 (28\%) females, Where as in HIV non reactive individuals $30(60 \%)$ was male and $20(40 \%)$ was females given (Table 2)..There was no statistical significance in sex distribution between HIV positive individuals and HIV negative controls.

\section{Opportunistic Infections}

The most commonly seen opportunistic infection seen in my study was oral candidiasis, pulmonary tuberculosis, PCP pneumonia all these opportunistic infections oral candidiasis was most prevalent among HIV positive individuals. In our study there was 35 patients were Vitamin D deficient $(<20 \mathrm{ng} / \mathrm{ml})$. When we compare 25 $(\mathrm{OH}) 2$ vitamin $\mathrm{D}$ levels with opportunistic infections in HIV positive patients, they had vitamin D deficiency ( $<20 \mathrm{ng} / \mathrm{ml})$. In our study w 30 patients $(60 \%)$ had vitamin D deficiency $(<20$ $\mathrm{ng} / \mathrm{ml}$ ), and $5(4 \%)$ had insufficiency (21 to 30 $\mathrm{g} / \mathrm{ml})$

Study by Sudfeld C R et al which compared the incidence of opportunistic infections and pulmonary tuberculosis with a low vitamin D levels. Individuals with vitamin D deficiency also had features of wasting (BMI < 18.5) and > 10\% of weight loss.

Our study showed that patients with low $25(\mathrm{OH}) 2$ vitamin D levels $(<20 \mathrm{ng} / \mathrm{ml})$ have increased incidence of opportunistic infections, which was statistically significant table (4)

\section{CD4 Count}

In our study $30(68 \%)$ patients had CD4 count $(<200), 8$ patients had $(12 \%)$ CD4 count 200-350 and $12(18 \%)$ persons had CD4 count $>350$ given in table (4). Study showed patients with CD4 count $<200$ had vitamin D deficiency $(<20$ $\mathrm{ng} / \mathrm{ml}$ ), about $60 \%$ of patients were vitamin D deficient, being statistically sifgnificant of $P$ value being 0.015 using ANOVA method.

Study conducted by Marian Aziz et al showed the association between vitamin D levels and CD4 count with womens in advanced disease on HAART. Study showed vitamin D insufficiency may impair CD4 recovery with advanced disease on HAART therapy.

Study conducted by Nicolas J. Muller et al showed the negative correlation of hepatitis $\mathrm{C}$ seropositivity with $1,25(\mathrm{OH}) 2$ vitamin $\mathrm{D}$ but not with $25(\mathrm{OH}) 2$ vitamin $\mathrm{D}$, related to an 
inflammation related impairment of 1hydroxylation if contraindicated by the unexplained negative correlation of $1,25(\mathrm{OH}) 2$ vitamin D with CD4 cell count.

\section{Patients on ART}

In our study there were 43 patients on ART of which 30 persons $(60 \%)$ had vitamin D deficiency (<20ng/ml), 12 persons(24\%) had vitamin D insufficiency (21-30) and 1 person (2\%) had vitamin $\mathrm{D}$ suffieciency. we have compared $25(\mathrm{OH}) 2$ vitamin D levels in patients on ART,25 $(\mathrm{OH}) 2$ vitamin $\mathrm{D}$ was deficient $(<20 \mathrm{ng} / \mathrm{ml})$ among patients on ART and was not statistically significant given in Table 5 of $\mathrm{P}$ vaue being 0.239 using chi-square test.

Study conducted by Nicolas J Muller et al found that cART exposure had no significant impact on vitamin D levels. NRTI was associated with significantly low $25(\mathrm{OH}) 2$ vitamin D levels. Neither NNRTI are PI medication showed a significant effect on 1, $25(\mathrm{OH}) 2$ vitamin D levels in their analysis, although PI treated patients had shown low 1,25 $(\mathrm{OH}) 2$ vitamin $\mathrm{D}$ values.

Paul TV et al in an Indian study from Christian Medical College, Vellore India found high prevalence of vitamin D deficiency (74\%) among HIV positive patients on HAART as compared to naïve and control group (37\% in each group). ${ }^{12}$

\section{Co-infections \\ HBsAg and HCV}

In our study 8 patients had HbsAg positive of which $7(14 \%)$ of patients had vitamin D deficiency. There was only $1(2 \%)$ patients with HCV positive status, given in table (6 and 7). There was no statistical significance using chisquare method.

In our study there was no correlation between vitamin D levels and co-infections like HbsAg and $\mathrm{HCV}$.

\section{Limitations of Study}

Less sample size is a limitation of the study.

\section{Conclusion}

- Our study revealed high prevalence of vitamin D deficiency among HIV positive patients.

- There was statistical significance between vitamin D levels, CD4 count and opportunistic infections in my study.

- HIV infected patients should be screened for vitamin D deficiency as there is high prevalence of vitamin D deficiency among these patients.

- If resources are not available to analyze the vitamin D status in these patients they should be supplemented with vitamin D to prevent the vitamin D deficiency and further complications.

- It is observed that pragmatic and statistical studies are scarcely done in India on the socially imperative subject of "VITAMIN D LEVELS IN HIV POSITIVE PATIENTS". It could be valuable in the larger interest of innumerable ailing patients if further studies are done to explore more practicable solutions to maintain the "Vitamin D levels in HIV positive patients".

\section{References}

1. Arya V,Bhambri R, Godbole MM, Mithal A. Vitamin D status and its relationship with bone mineral density in healthy Asian Indians. Osteoporos Int.2004; 15 :56-61.

2. Sachan A, Gupta R, Das V. High prevalence of vitamin D deficiency among pregnant women and their newborns in northern In dia. Am J Clin Nutr.2005; 81: $1060-1064$.

3. Puri S, Marwaha RK, Agarwal N. Vitamin D status of apparently healthy school iris from two different socioeconomic strata in Delhi: relation to nutrition and lifestyle. BrJ Nutr.2008; 99:876-882.

4. Sahu M, Bhatia V, Aggarwal A, Rawat V, Saxena P. Vitamin D deficiency in rural girls and pregnant women despite 
abundant sunshine in northern India. Clin Endocrinol (Oxf).2009 May;70(5):680-4.

5. Tang AM, Graham NM, Kirby AJ, McCall LD, Willett WC, Saah AJ. Dietary micronutrient intake and risk of progression to acquired immunodeficiency syndrome (AIDS) in human immunodeficiency virus type I (HIV -1 )infected homosexual men. AmJ Epidemiol. 1993;138:937-951.

6. Fawzi WW, Msamanga GI, Spiegelman D.A randomized trial of multivitamin supplements and randomized trial of multivitamin supplements and $\mathbf{J}$ Med. 2004;351:23-32

7. Tebas P, Powderly WG, Claxton S. Accelerated bone mineral loss in HIVinfectedpatients receiving potent antiretroviral therapy. AIDS 2000;14:F63F67.

8. Moore AL, Vashisht A, Sabin CA. Reduced bone mineral density in HIV positive individuals. AIDS 2001; 15: 1731-1733.

9. Garcia Aparicio AM, Mun - oz Fernandez S, Gonzalez J. Abnormalities in the bonemineral metabolism in HIV- infected patients. Clin Rheumato12006;25:537539.

10. Tangpricha V, Pearce EN, Holick MF. Vitamin D insufficiency among free-living healthy young adults. Am J Med. 2002;112:659-662.

11. Bhalla AK, Amento EP, Clemens TL, Holick MF, KraneSM..Specific highaffinity receptors for 1,25 dihydroxyvitamin D3 in human peripheral blood mononuclear cells: presence in monocytes and in-duct ion in $T$ lymphocytes following activation. J Clin Endocrinol Metab. 1983;57: 1308-1310.

12. Paul TV, Asha HS, Thomas N, Seshadri MS, Rupali P. Hypovitaminosis D and bone mineral density in human immunodeficiency virus-infected men from India, with or without antiretroviral therapy. Endocr Pract. 2010 JulAug;16(4):547-53.

13. Dao CN, Patel P, Overton ET, Rhame F, Pals SL, Johnson C. Low vitamin D among HIV -infected adults: prevalence of and risk factors for low vitamin D Levels in a cohort of HIV-infected adults and comparison to prevalence among adults in the US general population. Clin Infect Dis. 2011 Feb;52(3):396-405. 